\title{
24. CHLOROPHYLL DIAGENESIS IN IPOD LEG 47A, SITE 397 CORE SAMPLES
}

\author{
E. W. Baker and S. E. Palmer, Department of Geology, Florida Atlantic University, Boca Raton, Florida
}

\section{INTRODUCTION}

Nine core samples from Holes 397 and 397A, ranging in age from Pleistocene to Early Cretaceous and 90 to 1440 meters depth of burial, were analyzed for tetrapyrrole pigment content by UV-visible spectrophotometry and mass spectrometry.

Our interest was directed toward characterizing the tetrapyrrole geochemistry of lower Miocene strata in these holes drilled on the continental margin off Cape Bojador on the west coast of Africa. Most of these strata were described by the shipboard party as containing abundant allochthonous material which was originally deposited in a low oxygen environment farther up-slope and as having a high organic content. Thus, we expected to find evidence of stratigraphic reworking, such as combinations of geochemically young (chlorins) and old (vanadyl porphyrins) tetrapyrroles in the same sediment sample or large differences in band widths or mass spectral envelopes of metalloporphyrins.

However, the electronic and mass spectrometric data indicated that the diagenesis of chlorophyll from these samples was not unlike that for other suites of samples from Legs 41 and 42B (Baker et al., 1978b, c). In these earlier studies and in this study, chlorins gave way to free-base and nickel porphyrins with increasing depth of burial, as is the usual case in the absence of reworking. The geochemical explanation for these changes in the chlorophyll molecule is well documented in marine sediments.

Of particular interest was the observation of odd molecular weight series of metalloporphyrins in the Miocene samples. Nickel porphyrins of odd molecular weights preclude normal structures containing carbon, hydrogen, oxygen, and even numbers of nitrogens, thus suggesting either odd-number nitrogen compounds or electron impact fragmentation in the mass spectrometer. Previously, porphyrins of this series have been observed, and mass spectrometrically characterized, accompanying chlorins and free-base porphyrins in Pleistocene and Cretaceous samples (Baker et al., 1978c, d; Palmer et al., in press). However, the initial observation of these porphyrins, based on their unique electronic spectrum, was in Miocene samples from the Norwegian Sea where they typically occur with chlorins and free-base porphyrins (Baker et al., 1976). The significance of these materials as diagenetic indicators is still not understood.

\section{EXPERIMENTAL}

Samples examined here were stored at 2 to $4^{\circ} \mathrm{C}$ for 3 weeks while in transit from the Glomar Challenger to
DSDP, Scripps Institution of Oceanography, where the cores were then frozen until the time of analysis. Depending on per cent organic carbon, 100 or 200 grams of sediment were extracted with acetone:methanol (90:10) in a ballmill until the extract was devoid of pigment. The type of pigment was determined by spectrophotometry using a Beckman Acta CIII scanning spectrophotometer. In samples containing only chlorins, the extracts were partitioned between 19 per cent (by weight) $\mathrm{HCl}$ and ethyl ether for purification. Similarly, samples containing chlorins or free-base porphyrins and nickel porphyrins were partitioned between 10 per cent $\mathrm{HCl}$ and ethyl ether. Repeated $\mathrm{HCl}$-ether partitioning and chromatography over Sephadex LH20 with THF as eluent further purified the free-base porphyrin fractions. Nickel porphyrin fractions were chromatographed over alumina grade III with cyclohexane followed by cyclohexane:benzene (1:1) which eluted the metalloporphyrins.

Mass spectrometric analyses of the free-base and nickel porphyrin fractions were made using a Dupont 491-BR mass spectrometer equipped with a direct probe inlet system. Temperatures used for the analyses of free-base porphyrins were $260^{\circ}$ to $305^{\circ} \mathrm{C}$ (source) and $270^{\circ}$ to $300^{\circ} \mathrm{C}$ (probe); slightly higher temperatures were used for analyses of nickel porphyrins, $285^{\circ}$ to $325^{\circ} \mathrm{C}$ (source) and $325^{\circ}$ to $360^{\circ} \mathrm{C}$ (probe).

\section{RESULTS}

\section{Distribution of Tetrapyrrole Pigments With Depth of Buriai}

Pigment UV-visible spectrophotometric data, pigment concentrations, and geologic data are given in Table 1. The table shows that the tetrapyrrole pigments can be divided into two types: chlorins occurring in the younger and shallower samples, and porphyrins occurring in the older and deeper samples.

The pattern displayed by the chlorin spectrophotometric data with increasing age/depth of burial has been discussed in detail by Baker et al. (1978c, d) and only needs to be mentioned here. With increasing age/ depth, the far red band shifts from $667 \mathrm{~nm}$ to lower wavelengths (664 to $657 \mathrm{~nm}$ ). Similarly, the Soret band shifts from $411 \mathrm{~nm}$ to lower wavelengths. The diagenetic changes responsible for these changes are probably related to reduction and loss of oxygen and carboxyl groups.

The spectra of the free-base porphyrins (Cores 397 A-12 through 397 A-23 at 1035 to 1160 meters) are typical of DPEP. Their concentrations tend to decrease relative to nickel porphyrins with increasing depth of burial. 
TABLE 1

Pigment Data From Leg 47A Core Samples

\begin{tabular}{|c|c|c|c|c|c|c|c|c|c|c|c|c|}
\hline $\begin{array}{l}\text { Section } \\
\text { No. }\end{array}$ & $\begin{array}{l}\text { Geologic } \\
\text { Age }\end{array}$ & $\begin{array}{l}\text { Lithologic } \\
\text { Description }\end{array}$ & Dsptha & $\begin{array}{l}\text { Organica } \\
\text { Carbon } \\
\text { (\% by wt.) }\end{array}$ & $\begin{array}{c}\text { Pigment } \\
\text { Concentration }^{b} \\
(\mu \mathrm{g} / \mathrm{g})\end{array}$ & \multicolumn{6}{|c|}{$\begin{array}{l}\text { Electronic Spectrum } \\
\qquad(\mathrm{nm})\end{array}$} & Pigment Type \\
\hline $397-10-6$ & Pleistocene & Blue-gray lime mud & $85-94.5$ & 0.6 & 0.06 & 411 & 500 & (530) & & $(607)$ & 667 & Chlorin \\
\hline $397-18-5$ & Late Pliocene & Green-gray lime mud & $161-170.5$ & 0.4 & 0.07 & 400 & & & & $(600)$ & 664 & Chlorin \\
\hline $397-32-2$ & Early Pliocene & Gray lime mud & $294-303.5$ & 0.3 & 0.01 & & & & & $(595)$ & 661 & Chlorin \\
\hline $397-68-2$ & $\begin{array}{l}\text { Late or middle } \\
\text { Miocene }\end{array}$ & $\begin{array}{l}\text { Blue and gray-green } \\
\text { lime mud }\end{array}$ & $645.5-655$ & 0.1 & $\begin{array}{l}0.004 \\
0.009\end{array}$ & 397 & & 521 & 557 & & 657 & $\begin{array}{l}\text { Chlorin } \\
\text { Nickel porphyrin (?) }\end{array}$ \\
\hline $397 A-12-2$ & Early Miocene & $\begin{array}{l}\text { Calc, dark green } \\
\text { mud }\end{array}$ & $1030-1039.5$ & 0.6 & $\begin{array}{l}0.23 \\
0.17\end{array}$ & $\begin{array}{l}402 \\
396\end{array}$ & 500 & $\begin{array}{l}533 \\
515\end{array}$ & $\begin{array}{l}565 \\
552\end{array}$ & 618 & & $\begin{array}{l}\text { Free-base porphyrin } \\
\text { Nickel porphyrin }\end{array}$ \\
\hline $397 A-16-4$ & Early Miocene & $\begin{array}{l}\text { Calc. dark gray mud } \\
\text { with gray calc. } \\
\text { clasts, petrol. odor }\end{array}$ & $1068-1077.5$ & 1.7 & $\begin{array}{l}0.46 \\
0.08\end{array}$ & $\begin{array}{l}403 \\
396\end{array}$ & 500 & $\begin{array}{l}533 \\
515\end{array}$ & $\begin{array}{l}565 \\
552\end{array}$ & 618 & & $\begin{array}{l}\text { Free-base porphyrin } \\
\text { Nickel porphyrin }\end{array}$ \\
\hline $397 \mathrm{~A}-21-2$ & Early Miocene & $\begin{array}{l}\text { Calc. sandy dark } \\
\text { green mud with } \\
\text { calc. blue-gray } \\
\text { clasts }\end{array}$ & $1115.5-1134.5$ & 0.4 & $\begin{array}{l}0.09 \\
0.06\end{array}$ & $\begin{array}{l}402 \\
396\end{array}$ & 500 & $\begin{array}{l}533 \\
515\end{array}$ & $\begin{array}{l}565 \\
552\end{array}$ & 618 & & $\begin{array}{l}\text { Free-base porphyrin } \\
\text { Nickel porphyrin }\end{array}$ \\
\hline $397 A-23-4$ & Early Miocene & $\begin{array}{l}\text { Calc. brown } \\
\text { green mud (forams } \\
\text { present) }\end{array}$ & $1153.5-1172.5$ & 0.6 & $\begin{array}{l}0.13 \\
0.26\end{array}$ & $\begin{array}{l}402 \\
396\end{array}$ & 500 & $\begin{array}{l}533 \\
515\end{array}$ & $\begin{array}{l}565 \\
552\end{array}$ & 618 & & $\begin{array}{l}\text { Free-base porphyrin } \\
\text { Nickel porphyrin }\end{array}$ \\
\hline $397 A-51-4$ & $\begin{array}{l}\text { Early } \\
\text { Cretaceous }\end{array}$ & $\begin{array}{l}\text { Calc. dark } \\
\text { gray mud }\end{array}$ & $1438.5-1448$ & 0.6 & 0.02 & 396 & & 515 & 552 & & & Nickel porphyrin \\
\hline
\end{tabular}

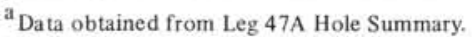

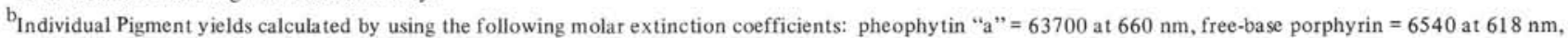
and nickel porphyrin $=34820$ at $550 \mathrm{~nm}$.

Nickel porphyrins occur with chlorins in Core $397-$ 68 , with free-base porphyrins in 397A cores of early Miocene age, and occur alone in the Lower Cretaceous Core 397A-51 at 1440 meters. The electronic spectra of the nickel porphyrin fractions from the lower Miocene to Lower Cretaceous samples are remarkably similar with an $\alpha$ absorbance band at $552 \mathrm{~nm}$ and a $\beta$ band at $515 \mathrm{~nm}$ (see Table 1); however, the $\alpha / \beta$ peak ratios increase from 2.1 in Core 397A-12 to 2.9 in Core 39751. An increase in this ratio with increasing depth of burial is indicative of an increase in the relative abundance of nickel etioporphyrins with respect to nickel DPEP. (Nickel etioporphyrin has an $\alpha / \beta$ ratio of about 3.0, while nickel DPEP has an $\alpha / \beta$ ratio of about 2.0.) The increasing amount of etioporphyrins relative to DPEP with depth is in accord with earlier observations. In fact, the DPEP/etio ratio may be taken as a reasonable measure of organic maturity.

However, the metalloporphyrin fraction isolated from Core 397-68 had an $\alpha / \beta$ peak ratio of 1.5 which falls outside the normal range for a nickel porphyrin and the visible bands were shifted towards longer wavelengths (Table 1). Both of these spectral features suggest substantially modified molecular structures or a different chelating metal, perhaps copper. Metalloporphyrins with this type of spectrum have been observed previously occurring with chlorins and free-base porphyrins in Miocene sediments from the NorwegianGreenland Sea (Baker et al., 1976).

\section{Mass Spectrometric Data of Free-Base and Nickel Porphyrins}

The mass spectrometric data for the porphyrins isolated from Holes 397 and 397A are given in Table 2; parameters generated from these data are given in Tables 3 and 4 .
Mass spectrometric data of free-base porphyrins obtained from organic extracts of lower Miocene Cores 397A-12 to 397A-23 were quite similar. Only porphyrins of the DPEP series were observed, with five members of the series present. Generally, the $C_{32}$ or $C_{31}$ porphyrin was more abundant as determined by normalizing the peak intensities (Table 2). Similar data have been obtained for free-base porphyrins isolated from other deep-sea sediments of Pleistocene to Cretaceous age (Baker et al., 1978a-c; Palmer et al., in press). Mass spectrometric parameters such as weighted average mean and band width also indicated that the porphyrin mixtures were similar (Table 3 ).

As has been the case in the past, mass spectrometric analyses of nickel porphyrins result in more complex data than free-base porphyrins isolated from the same sediment samples. For this reason, the nickel porphyrin mass spectrometric data have been studied in such a way that several characteristics can be observed with increasing age/depth. First, the peak intensities of each series were normalized to determine the shape of the individual mass spectral envelopes and the relative abundances of each series (Table 2). Then, the DPEP/ etio ratio and the per cent abundance of the odd molecular weight series were determined along with band width and average weighted mass (Table 4).

The nickel porphyrins from lower Miocene Cores 12, 16, 21, 23 from Hole 397A have similarly shaped mass spectral envelopes with the mode at either the $C_{31}$ or the $\mathrm{C}_{30}$ DPEP series member and, typically, a mode one to three carbons less for the etio series (Table 2). Both the DPEP and etio series are composed of five to seven members. The DPEP/etio ratio tends to decrease with increasing depth of burial, with the sample from Core 397A-21 being a modest exception. This trend was also reflected in the change in the $\alpha / \beta$ ratios of the 
TABLE 2

Mass Spectral Data of Free-Base and Nickel Porphyrins ${ }^{\mathrm{a}}$ From Holes 397, 397A

(peak intensities normalized to 100 for the most intense peak)

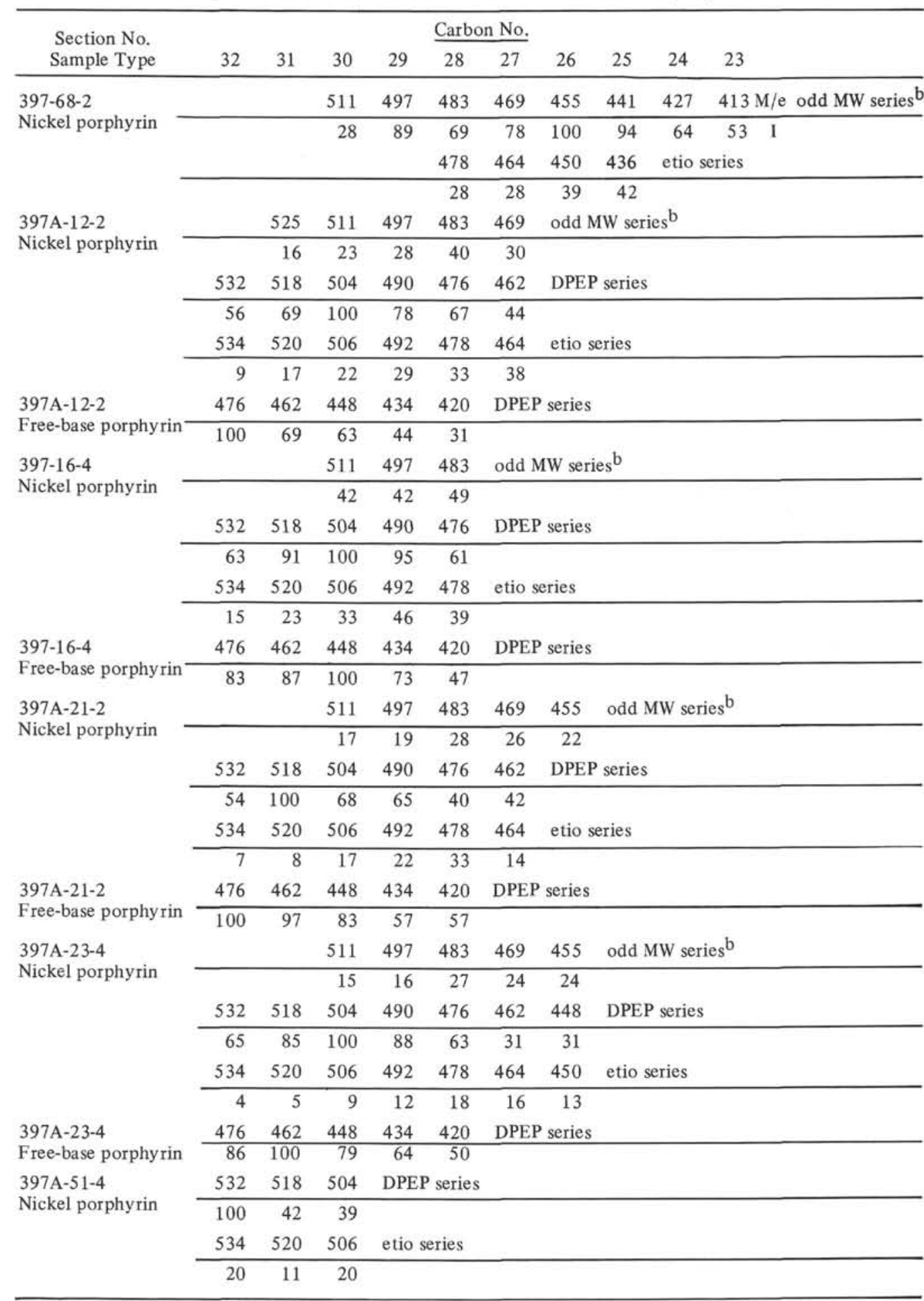

${ }^{\mathrm{a}}$ The peak heights (I) for nickel porphyrins of the etio series have been corrected for the $\mathrm{Ni} 60$ contribution from the corresponding DPEP series.

These metalloporphyrins have molecular weights coincident with copper etioporphyrins.

visible bands in the electronic spectra as mentioned earlier.

The band width for the DPEP series ranges from 18 to 31 , while the values range from 20 to 31 for the etio series. In contrast with nickel porphyrin samples from Legs 40 and 44 (Baker et al., 1978a, d), there is little difference between the band widths for the two series within the same sample. Large differences in band 
TABLE 3

Mass Spectrometric Parameters of Free-Base Porphyrins, Leg 47A

\begin{tabular}{lcc}
\hline $\begin{array}{c}\text { Section } \\
\text { No. }\end{array}$ & $\begin{array}{c}\text { Weighted } \\
\text { Av. Mean }\end{array}$ & $\begin{array}{c}\text { Banda } \\
\text { Width }\end{array}$ \\
\hline 397 A-12-2 & 452 & 19 \\
$397 \mathrm{~A}-16-4$ & 452 & 19 \\
$397 \mathrm{~A}-21-2$ & 455 & 18 \\
$397 \mathrm{~A}-23-4$ & 451 & 18 \\
\hline a & \multicolumn{2}{c}{ Table 4 for calculation of } \\
weighted average mean and band \\
width.
\end{tabular}

widths and bimodal molecular weight distributions would suggest stratigraphic reworking. Evidence for reworking is not present in the data for these particular samples.

In addition to these two series, the odd molecular weight series occur seven mass units distant from the corresponding nickel DPEP value. This series is composed of three to five members with a mode corresponding to a $\mathrm{C}_{28}$ porphyrin and is present in amounts ranging from 13 to 10 per cent.

Upper Miocene Section 397-68-2 contained a nickel porphyrin fraction with a noticeably different electronic spectrum than those of the lower Miocene discussed earlier. The mass spectrometric data show that the mixture had a very high content $(81 \%)$ of the as yet unidentified odd molecular weight series and a lesser amount of a highly dealkylated nickel etioporphyrin series. In Section 397-68-2, the unidentified series is composed of eight members with a mode corresponding to a $\mathrm{C}_{26}$ porphyrin and has a band width of 31 (Tables 2 and $4)$. The relative abundance of this series tends to decrease in abundance with increasing depth of burial in samples from the lower Miocene and is absent in Lower Cretaceous section 397A-51-4. Band widths tend to decrease, while the average molecular weight abruptly increases in the lower Miocene samples (Table 4).

The metalloporphyrins that are mass spectrometrically observed as an odd molecular weight series $(455+14 n)$ have not been structurally characterized. If these unidentified porphyrins are indeed nickel chelates, their odd molecular weights preclude normal structures containing carbon, hydrogen, oxygen, and even numbers of nitrogens suggesting either molecular ions of odd-number nitrogen compounds or electron impact fragments created in the mass spectrometer. These porphyrins have been mass spectrometrically observed previously and occur with chlorins and free-base porphyrins in Pleistocene to Miocene sediments of the Black Sea, and in Cretaceous sediments from BlakeBahama Basin and Bermuda Rise (Baker et al., 1978c, d; Palmer et al., in press). The electronic and mass spectra for the metalloporphyrin extract from Section 397 68-2 are the best data set thus far available for characterization of the $455+14 \mathrm{n}$ series. Previously, only the electronic spectrum was recorded (Baker et al., 1976) or the series, being a smaller component in the mixture, was observed only in the mass spectrum. This ap-
TABLE 4

Mass Spectrometric Parameters of Nickel Porphyrins, Leg 47A

\begin{tabular}{|c|c|c|c|c|c|}
\hline $\begin{array}{l}\text { Section } \\
\text { No. }\end{array}$ & $\begin{array}{l}\text { Odd MW } \\
\text { Series }(\%)\end{array}$ & $\begin{array}{l}\text { DPEPEI/a } \\
\text { etio } \Sigma 1\end{array}$ & $\begin{array}{l}\text { Weighted } \\
\text { Av. Mean }\end{array}$ & $\begin{array}{l}\text { Bandc } \\
\text { Width }\end{array}$ & Porphyrin Series \\
\hline $397-68-2$ & 81 & 0 & $\begin{array}{l}460 \\
454\end{array}$ & $\begin{array}{l}31 \\
15\end{array}$ & $\begin{array}{l}\text { Odd MW series } \\
\text { etio series }\end{array}$ \\
\hline $397 A-12-2$ & 18 & 3.0 & $\begin{array}{l}492 \\
498 \\
489\end{array}$ & $\begin{array}{l}27 \\
31 \\
31\end{array}$ & $\begin{array}{l}\text { Odd MW series } \\
\text { DPEP series } \\
\text { etio series }\end{array}$ \\
\hline $397 A-16-4$ & 20 & 2.6 & $\begin{array}{l}496 \\
504 \\
500\end{array}$ & $\begin{array}{l}20 \\
18 \\
20\end{array}$ & $\begin{array}{l}\text { Odd MW series } \\
\text { DPEP series } \\
\text { etio series }\end{array}$ \\
\hline $397 \mathrm{~A}-21-2$ & 19 & 3.7 & $\begin{array}{l}481 \\
502 \\
491\end{array}$ & $\begin{array}{l}19 \\
22 \\
20\end{array}$ & $\begin{array}{l}\text { Odd MW series } \\
\text { DPEP series } \\
\text { etio series }\end{array}$ \\
\hline $397 \mathrm{~A}-23-4$ & 13 & 2.1 & $\begin{array}{l}480 \\
497 \\
481\end{array}$ & $\begin{array}{l}19 \\
24 \\
23\end{array}$ & $\begin{array}{l}\text { Odd MW series } \\
\text { DPEP series } \\
\text { etio series }\end{array}$ \\
\hline $397 \mathrm{~A}-51-4$ & 0 & 1.6 & $\begin{array}{l}523 \\
520\end{array}$ & $\begin{array}{l}11 \\
12\end{array}$ & $\begin{array}{l}\text { DPEP series } \\
\text { etio series }\end{array}$ \\
\hline
\end{tabular}

${ }^{a}$ Obtained from Table 2;1 is mass spectral peak intensity.

Corresponds to the weighted average mass, obtained by $\Sigma I M / \Sigma I$ from Table 2 .

The band width is given as the standard deviation $(\sigma)$ in mass units, computed according to the formula $\sigma=\sqrt{\Sigma\left(1 M^{2}\right) / \Sigma I-(\Sigma I M / \Sigma I)^{2}}$ where $I$ is the intensity and $\mathrm{M}$ the mass, both taken from Table 2 .

pears to be the case for samples from Cores 12 through 23 from Hole 397A, where the more typical DPEP and etio series porphyrins predominate (Table 4).

Only three members of the DPEP and etio series were observed in the mass spectrum of the nickel porphyrin fraction from Section 397A-51-4. No odd molecular weight porphyrins were present. The significance of the data for this sample cannot be clearly stated because of the small amount of pigment being analyzed (approximately $1 \mu \mathrm{g}$ ) and the amount of impurities still remaining after chromatography over alumina. If lesser amounts of either members of the odd molecular weight series or the DPEP and etio series were present in the mixture, their presence was not detectable because of sample quality. Sample size may also account for the narrow band widths of 11 and 12 for the two series (Table 4).

\section{DISCUSSION}

The diagenetic pathway of chlorophyll in marine settings is fairly well exemplified by the Pleistocene to Lower Cretaceous cores from Site 397, located on the continental margin off Cape Bojador on the west coast of Africa. One major gap in the sample collection, between 650 to 1035 meters, causes the pathway to be incomplete.

In the Pleistocene to upper Miocene samples, at 90 to 650 meters, early chlorophyll diagenetic products (chlorins) progressively changed, probably through reduction, loss of oxygen, and decarboxylation, from a pheophytin or pheophorbide-type pigment to perhaps a deoxomesopyropheophorbide type. (These structural types have been discussed and more thoroughly described by Baker et al., 1978c, d. No absolute structures can be assigned to these geochlorins until more complete mass spectrometric analyses are made.) The concentration of the chlorins follows that of the organic carbon, i.e., decreasing with increasing depth of burial. 
Following these observable initial changes in the chloropohyll molecule, free-base deoxophylloerylthro(tioporphyrin (DPEP) type pigments appear in older/ deeper early Miocene samples. Chlorins, absent from these particular samples, have been found in samples of equivalent age and older, but at shallower depths. This fact suggests that depth of burial (greater than $1000 \mathrm{~m}$ ) plays a more important role in diagenesis than geologic age.

Nickel porphyrins are also present in the lower Miocene samples as well as in the Cretaceous sample at approximately 1440 meters. Comparison of the $\alpha / \beta$ visible bands and DPEP and etio mass spectral peak intensities shows that the etioporphyrins increase with depth relative to the DPEP types; however, the DPEP series predominates throughout. Some conversion to the etio series by isocyclic ring opening has occurred; however, thermal stresses have not been great enough to cause a significant shift in the DPEP/etio ratio. In addition, no vanadyl porphyrins were found, which may also suggest mild geothermal conditions (Baker et al., 1978b).

Perhaps samples from 700 to 900 meters would have contained a mixture of chlorins and free-base porphyrins, which has been referred to as the chlorinporphyrin transition (Baker et al., 1978c). This gap in the sample collection makes the similarity of the tetrapyrrole mixtures in lower Miocene samples more apparent. In turn, the pigment distribution in these four samples contrasts with the chlorin and odd molecular weight nickel porphyrin in the upper Miocene sample above and the nickel porphyrins below in Section 397A-51-4. These four samples would all be assigned to the F-3 and $4 \mathrm{~A}_{2}$ lithotypes which consist of rapidly deposited organic-rich sediments (O. Weser, personal communication). The similarities among the pigment content are explained by the uniformly high amount of allochthonous material associated with these lithotypes. Although the particular samples used for this study were poorly sorted and two (Cores 16 and 21 , Hole 397A) contained observable carbonate clasts, no geochemical evidence of stratigraphic reworking was found. This suggests that the major contribution came from the same or a similar source, most probably the organic-rich sediments originally deposited up-slope in an oxygen-poor environment. Contributions of pigments by hemipelagic mud, here seen as clasts, would be expected to be small. This suggestion is based on the low concentrations of pigments associated with lime muds in general (see Baker et al., 1978b; Palmer et al., 1978).

Although the study of Leg 47A core samples did not lead to expansion of the application of the tetrapyrrole pigments as indicators of stratigraphic reworking, it did provide an opportunity to better characterize the odd molecular metalloporphyrin series. Further study will be needed to clarify the geochemical significance of these pigments and to propose a probable chemical structure. Their presence may be indicative of an intermediate diagenetic stage since, when observed, they occur with chlorins and free-base porphyrins; or their presence may indicate an input of organic matter from a source different from that of the chlorins and freebase porphyrins.

\section{ACKNOWLEDGMENTS}

This research was supported by the Oceanography Section of the National Science Foundation, Grants DES 74-12438 AOI and OCE 74-12438 AO2. The authors thank Dr. Jean K. Whelan, Department of Chemistry, Woods Hole Oceanographic Institution, for her review of the manuscript and Drs. Roy R. Lemon and David L. Warburton, Department of Geology, Florida Atlantic University, for their helpful comments.

\section{REFERENCES}

Baker, E. W., Palmer, S. E., and Parrish, K. L., 1976. Tetrapyrrole pigments in DSDP Leg 38 sediments. In Talwani, M., Udintsev, G., et al., Initial Reports of the Deep Sea Drilling Project, v. 38: Washington (U.S. Government Printing Office), p. 785.

Baker, E. W., Palmer, S. E., and Huang, W. Y., 1978a. Chlorin and porphyrin geochemistry of DSDP Leg 40 sediments. In Bolli, H. M., Ryan, W. B. F., et al., Initial Reports of the Deep Sea Drilling Project, Supplement to Volumes $38,39,40$, and 41: Washington (U. S. Government Printing Office), p. 639-648.

1978b. Intermediate and late diagenetic tetrapyrrole pigments, Leg 41: Cape Verde Rise and Basin. In Lancelot, Y., Seibold, E., et al., Initial Reports of the Deep Sea Drilling Project, v. 41: Washington (U.S. Government Printing Office), p. 825-838.

1978c. Early and intermediate chlorophyll diagenesis of Black Sea sediments: Sites 379, 380 and 381 . In Ross, D., Neprochnov, Y., et al., Initial Reports of the Deep Sea Drilling Project, v. 42, Part 2: Washington (U.S. Government Printing Office), p. 707-716.

1978d. Miocene and Cretaceous tetrapyrrole pigments from Leg 44, Site 391. In Benson, W. E., Sheridan, R. E., et al., Initial Reports of the Deep Sea Drilling Project, v. 44: Washington (U.S. Government Printing Office), p. 639-644.

Palmer, S. E., Huang, W. Y., and Baker, E. W., in press. Tetrapyrrole pigments from Bermuda Rise: DSDP Leg 43. In Tucholke, B., Vogt, P., et al., Initial Reports of the Deep Sea Drilling Project, v. 43: Washington (U.S. Government Printing Office). 